\title{
Democracy, Decentralization and Efficientcy: A Study of Bureaucratic Reforms in Indonesia
}

\author{
Priyatno Harsasto ${ }^{1 . *}$ and Susilo Utomo ${ }^{1}$ \\ ${ }^{1}$ Government Departement, Universitas Diponegoro J1. Prof. H. Soedarto, S. H. Tembalang Semarang, Indonesia
}

\begin{abstract}
This research will investigate how bureaucratic reforms in the context of decentralization impact on state bureaucratic capacity in Indonesia. It argues that bureaucratic reforms in Indonesia has resultin a two-particular political outcomes. Firstly, to strengthen government political control over the bureaucracy by swinging back the decentralization approach toward a prefectoral system as a mean of changing the political arena in their favor, and, secondly, to gain popular support. In this way, bureaucracy reforms have indeed increased efficiency of the public sector, butat the same time decrease its autonomy. Democracy, decentralization, hybrid regime, partial bureaucracy reforms.
\end{abstract}

Keywords: Democracy; Decentralization; Hybrid Regimes; Efficiency; Autonomy.

\section{Introduction}

The implementation of decentralization policy after the fall of President Suharto, who had been in power for 32 years from 1966 to 1998 has made Indonesia one of the most pluralistic democracies in Southeast Asia. There have been a wide range of political reforms conducted accordingly. The reform ended the authoritarian military regime and replaced it with a democratic multiparty system. The reform was a "big bang" approach to wide-ranging decentralization by giving both greater political power and financial capacity to local governments. Under the decentralization policy the central government had only managed five authorities namely: international affairs, defence, monetary policy, religion and judiciary. Undoubtedly Indonesia had democratized, however, it was not without its old defects. "Hybrid regime," or "patrimonial regime" is the term that has been used to describe the new polity as Indonesia transits from a procedural democracy to a consolidation democracy. In this so called hybrid regime, checks and balances against centralized government have been implemented, but many would admit that the scourge of the New Order patronage system and other ills has not entirely been abolished from the system. It is argued that oligarchic system under Suharto survived and merely reorganized themselves in accordance to the new political climate[1]. In practice "big bang decentralization" has created many problems related to the emergence of corruption decentralization, communal conflict and disputes in allocation of natural resources[2].
It seems that decentralization in Indonesia, with its local direct elections and wide representation of different interests in power structures, is necessary but might not be a sufficient condition for solving NKK (Nepotism, Collusion and Corruption), since it does not account for the ability of governments to implement policies. In this way the focus of Indonesian government on building democracy, also underscores the importance of developing bureaucratic capacity in reaching desirable policy outcomes. While democracy level, especially local democracy, can determine how different issues are brought up on the political agenda and how political decisions are made, bureaucratic capacity, determines whether and how the decisions are implemented. Bureaucratic reforms aim at developing bureaucratic capacity which characterized by the absence of corruption and meritocratic employment. In this context this research will investigate how bureaucratic reforms impact on state bureaucratic capacity in Indonesia. How government organization reforms impact on the power relationship between national government and the local one? How this reform determines public support through developing bureaucratic capacity?

\section{Methodology}

This article uses case study as a strategy to conduct the research. Case study arise for the need of understanding the complex social phenomenon. In this way, the researcher can obtain a detailed and intensive examination of a particular case or cases

\footnotetext{
*Corresponding author: harunosa@yahoo.com
} 
that are rooted in a specific context. The need to scrutinize the practice of bureaucratic reforms as part of regime survival strategy that is manifested in the process of exchange, negotiation and domination in bureaucratic reforms in hybrid regime provide the justification. Hybrid regimes are partial democracy regimes, namely regimes where formally democratic institutions co-exist with authoritarian governance practices.

\section{Discussion}

According to Sung countries stand in the grey zone between liberal democracy and authoritarianism, tend to be the worst performers compare to autocracy and democracy[3]. From the supply side, autocracies can be effective at holding a strong hold of the bureaucracy apparatus from above, by virtue of their repressive capacity. While from the demand side, democracies perform well due to their extensive steering mechanisms from below. There is a weakness of both sides in Hybrid regimes. Hybrid regimes have weaken their top-down of management.

Election is not just a symbolic activities such as in an autocratic regimes. The elections have to be meaningful for the people in Hybrid regimes. Votes do matter in this political playing fields[5]. By virtue of managing regular multiparty elections for the government offices, incumbents 'creates the primacy of democratic legitimation'. Hybrid regimes depend on a large 'electorate', which means that meeting public needs is very important. This is all the more clear when we remembered the "small window of uncertainty" for opposition parties that regular multiparty elections carry, and democratizing potential of such elections[7]. Incumbents here not only try to win the political arena, but also struggle to gain public support, as an important part of their political strategy. It is a struggle for reducing the risks of "democratic uncertainty", while "reaping the fruits of electoral legitimacy"[8].

Post-Suharto governments have lost centralized control mechanisms of autocrats, while this 'weakness' is not supplemented by democratic mechanism from below. The low performance in hybrid regime is caused by the inability of political competitors to make credible pre-electoral promises to voters[4]. This makes them to overprovide targeted-, and underprovide public goods. In hybrid regimes the insulation of government from the citizens' demands allows them to do costly investments in bureaucracy capacity. The governments have created and 'fine-tuned various complementary strategies' for development. They demand maintaining their power base, while retaining democratic legitimacy[5]. There is incentive structures of the state administrative capacity that can be used by rulers in hybrid regimes. These incentive structures allow them to control from above. There are a two-dimensional survival logic. On the one hand, to reduce the uncertainty that inevitably comes from allowing open electoral contest, incumbents try hard to create an uneven political playing field. Elections are important, that is why the ruling party make use state resources excessively that the opportunity of an opposition victory are significantly rare. According to Levitsky and Way there are three ways of particular importance in tilting the political playing field: access to state administrative resources, media and discretionary use of legal instruments[6].

Bureaucratic reform national policies set forth in Presidential Decree No. 17 Year 2007 on National Long Term Development Plan 2005-2025 which states that the development of the state apparatus made through bureaucratic reform to improve the professionalism of the state apparatus, as well as good governance and clean government apparatus in the center and regions, in order to be able to support the successful development in other fields[9]. The government believed in the advantage of a small government, and that limiting contact between civil servants and citizens was the key to efficient service delivery. Following global trend, the government adopt the New Public Management (NPM) model of bureaucracy. Apart from these proactive efforts to make the civil service more "customer aware", the government also extensively made use of media to publicize the reforms and, accordingly receive popular support. Corrupt government officials were often arrested in front of mass media, especially television-crews. This actions were symbolized a departure toward a better government.

Civil servants were meritocratically recruited to attract bright candidates. The government offered high salaries and continuous professional trainings for new recruits. However, the incumbent government still can obtained the loyalty of new recruits using clientalistic relation. Civil Service Law did not explicitly forbid partisan intervention in bureaucratic activities. The government occasionally created special post for those who were considered loyal to them. As a result civil servants were loyal to their supervisors instead of the institution or agency they worked at. It was not surprising when their supervisors were transferred to a different department, they will bring their subordinates with them too. Loyalty instead of seniority has been used as important parameter for promotion. In Central Java Province some young officials were promoted surpassing their seniors. To make the matter worse, important official posts were traded. The head of National Civil Service Comission (KASN) noted that total transaction of civil service posts in 2016 as high as Rp.36,7 trillion. Klaten regent was arrested by Anti Corruption Commision (KPK) due to trading local civil service posts. Secondly, the introduction of transparent e-procurement systems in many cases would not hinder the practice of spoill system. 
Important projects often distributed to businessmen connected to the incumbent (usually the businessmen who in the election period supporting the incumbent financially). The mayor of Tegal regency, for instance, skillfully manipulated the procurement system before finally captured by KPK. These noncompetitive contracts often geared to the supply of public goods and services that were of mediocre quality.

Bureaucrats seem to be trapped in a tug of war between the survival incentives of the regime. On the one hand, bureaucracy is at the heart of an incumbent's ability to maintain an uneven political arena. Control over the bureaucracy guarantees the ruling elite access to state resources and the possibility of employing it for partisan purposes. On the other hand, a well-functioning bureaucracy is a crucial aspect for citizens' satisfaction and thereby for generating votes. There is increasing evidence suggesting that voters reward politicians seen to be delivering public goods. An effective public service is vital for the successful provision of such essential goods. Even in highly clientelistic environments, incumbents who wish to get re-elected should seek to meet voter demands including delivering publicgoods": strong economic performance tends to favor the incumbent and reduce the possibility of oppositional victories. President Jokowi in an effort to gain public support focused on improved public service delivery, especially in the area of infrastructure development, business climate, education and health as the core aspect of his plathform. He used his down to earth approach to create man-of-the people image as a mean to unite voters to his couse. In recent survey conducted by Indo Barometer (March 2017) revealed that $66.4 \%$ of the population satisfied with government performance. While in the regional level, regions which in the hand of government party, Indonesia Democratic Party Struggle (PDIP), Central Java and Special region Yogyakarta were awarded the best bureaucratic performers 2017.

As a part of important political reform in the year 2000 the government adopted a wide range of decentralization programs. The reforms gave greater authority, political power, and financial resources directly to regencies and municipalities, bypassing the provinces. The powers transferred include those of executing a wide range of responsibilities in the areas of health, primary and middle-level education, public works, environment, communication, transport, agriculture, manufacturing, and other economic sectors. Laws No. 22/1999 and No. $32 / 2004$ give authority to local governments to execute a wide range of responsibilities in areas such as health, education, public works, environment, communication, transport, agriculture, manufacturing industry and trade, capital investment, land, cooperatives, labor force, and infrastructure services. The national government gave political authorities and financial resources to local government, bypassing the provincial government.

In terms of the environment, with regional autonomy, it is important for Indonesia to implement decentralization of environmental governance as an alternative effort to solve environmental problems. In the case of delegation of authority to the regional government in the field of natural resource management and environmental conservation, the intention is to increase the role of local communities in the protection and management of the environment. In principle, the decentralization policy is aimed at strengthening the capacity of local governments in improving the welfare of the community through public services and strengthening democracy at the local level. Decentralization of environmental management is expected to improve the quality of the environment by providing excellent service for the community, convenience in access information, increase community participation and environmental law enforcement [11].

The enactment of Law No. 23/2014 ended the application of Law No. 32/2004. The principle of deconcentration is still regarded as a complementary one but has a decisive role to support decentralization. In this new Law, forms of decentralization is more decisive, and hierarchical than in the Law No. 32/2004. This law swings back the local government approach towards the prefectural system which has been abandoned since the application of the Law 22/1999. The need for institutions that ensure cohesion and some kind of standardization and coordination within patrimonial state, appears crucial.We can find the clauses that arrange the hierarchichal relationship between central and regional government (clause 2 to 4 Law $23 / 2014$ ). The flavor of centralization can be feel in the clause 5 to 8 that regulates government power as embodied in the figure of the president as the origin of all matters distributed to the regions and a central figures in general, as mentro and supervisor in the implementation of decentralization. It is generally agreed that prefectoral systems underpin and serve as the basis for centralization. A prefect is a central state official in the region. The prefect is required to supervise and control local government actions as well as ensure that tasks are performed according to legal rules[10]. The law 23/2014 strengthens the governor as central government's representative in the regions ' in response to many instances where the governor's authority is seen to be weak since regional autonomy came into effect. The governor as prefect ensures standardization in administrative performance across regions in a unified state. These characteristics create the truism that the prefect serves as a tool for the central government and central control, and that prefectural systems may be regarded as arrangements that limit local discretion. 


\section{Conclusion}

The interaction among democracy, decentralization level as well as bureaucratic capacity is especially important for those structural problems that demand long-term consideration from governments that cannot be resolved by short-term exchanges in electoral promises. While political leaders are known to think in short-term period due to incessant political challenge through voting cycles, high bureaucratic capacity in democracies stands as a buffer against policy changes when new governments take control. This will assure the longterm government commitments. However, in democratic transition country such as Indonesia the capacity of bureaucracy is low. Democracy cannot flourish in a country with low bureaucratic capacity. That is why bureaucratic reforms become priority for indonesia governments.

This research has found that by decentralizing service delivery, recruiting high class cadres, renewing technology and employing private sector managerial principles, the Indonesiagovernment has significantly strengthened the capacity of bureaucracy to provide public goods and services thus affirm legitimacy. At the time, the government also secure access to financial as well as administrative resources and dominate the political game. However the efforts to boost the efficiency of public service have beenaccompanied by the government action to limit bureaucracy autonomy. The enactment of Law No 23/2014 ensures that the recentralization process has been finalized. National government controls over provinces becoming stronger. The developmentof bureaucrats and politicians careers have been relying on personalities as opposed to institutions. Accordingly, this unhealthy job environment, has encouraged loyalty of civil servants to the incumbent government. In this way, by reforming the bureaucracy the government has been successful increasing efficiency of the public sector, but at the same time decreasing bureaucratic autonomy.

\section{References and Notes}

1. A. Edward, The Irony of Success, Journal of Democracy, 21, 2, [20-34] (2010).

2. M. Bunte and A. Ufen, Indonesia's protected decentralization: contested reform and their unintended consequences, Democratization in post-Suharto Indonesia, Routledge Contemporary Southeast Asia Series (2008).

3. Sung, and Hung-En, Democracy and Political Corruption: A Cross-National Comparison, Crime, Law and Social Change, 41, 2: [179193] (2004).

4. P. Keefer, Clientelism, Credibility, and the Policy Choices of Young Democracies, American Journal of Political Science 51, 4: [804-821] (2007).

5. A. Schedler, The Nested Game of Democratization by Elections, International Political Science Review 23, 1: [103-122] (2002).

6. S. Levitsky, and L. A. Way, The Rise of Competitive Authorianism, Election Without Democracy (2010).

7. S. I. Lindberg, The Surprising Significance of African Elections, Journal of Democracy, 17, 1: [139-151] (2006).

8. A. Schedler, The Menu of Manipulation, Journal of Democracy, 13, 2: [36-50] (2002).

9. Bappenas, Pengembangan Ekonomi Daerah dan Sinergi Kebijakan Investasi Pusat-Daerah, Jakarta, Ringkasan Eksekutif Bappenas (2007).

10. G. Smith, The Local-Central Axis, London, Heinemann Educational (1976).

11. Muhammad Akib, Wewenang Kelembagaan Pengelolaan Lingkungan Hidup di Era Otonomi Daerah, Jurnal Media Hukum, 19, 2, (Desember 2012): 240 . 